\title{
PENGGUNAAN MEDIA EDUKASI HITUNG KOMPAK DAN DAMPAKNYA TERHADAP KEMAMPUAN BERHITUNG SISWA SEKOLAH DASAR
}

\author{
Agustan Syamsuddin ${ }^{1^{*}}$, Asrul Lukman ${ }^{2}$ \\ ${ }^{1}$ Program Studi Magister Pendidikan Dasar, Program Pascasarjana Universitas Muhammadiyah \\ Makassar, Indonesia \\ ${ }^{2}$ Prodi PGSD, FKIP Universitas Muhammadiyah Makassar, Indonesia \\ Korespondensi. E-mail: agustan@unismuh.ac.id
}

\begin{abstract}
Abstrak
Penelitian ini bertujuan untuk mengetahui gambaran pengaruh penggunaan media edukasi "Hitung Kompak" terhadap kemampuan berhitung pada siswa sekolah dasar. Penelitian ini termasuk penelitian pra-eksperimen yang melibatkan 36 siswa sebagai subjek penelitianyang terdiri atas 18 siswa laki-laki dan 18 siswa perempuan. Rancangan penelitian yang digunakan adalah One Group Pretest-Posttest Design dengan melibatkan satu kelompok subjek. Penelitian ini dilaksanakan melalui tahap perencanaan, pelaksanaan (pre test, treatment dan post test), analisis dan temuan penelitian.Instrumen yang digunakan dalam penelitian ini adalah tes hasil belajar siswa yang menggambarkan kemampuan berhitung siswa dan lembar observasi. Data hasil penelitian selanjutnya dianalisis dengan menggunakan teknis analisis statistik deskriptif dan analisis inferensial.Data yang diperoleh berupa data kuantitatif hasil tes kemampuan berhitung pada materi volume kubus dan balok selanjutnya analisisdengan menggunakan analisis deskriptif dan uji t-tes. Dari hasil penelitian diperoleh nilai rata- rata pre testsebesar58.61 yang termasuk pada kategori sedang. Sementara nilai rata-rata post test yang diperoleh sebesar 80 yang berada pada kategori tinggi. Berdasarkan hasil analisis uji t-tes diperolehnilai $t_{\text {Hitung }}=15.39$ dan $t_{\text {Tabel }}=3.591$, sehingga dapat dituliskan $t_{\text {Hitung }} \geq t_{\text {Tabel }}$ atau $15.39 \geq 3.591$. Dengan demikian, dapat disimpulkan bahwa $H_{o}$ ditolak dan $H_{1}$ diterima yang menggambarkan bahwa penggunaan media edukasi "Hitung Kompak" dapat memberi pengaruh dalam meningkatkan kemampuan berhitung siswapada materi volume kubus dan balok.
\end{abstract}

Kata Kunci:media edukasi, hitung kompak, kemampuan berhitung

\section{THE USE OF "COMPACT COUNTING" EDUCATIONAL MEDIA AND ITS IMPACTS ON PRIMARY SCHOOL STUDENTS'S COUNTING ABILITY}

\begin{abstract}
This study aims to describe the impact of the use of "Compact Counting" educational media on numeracy skills in elementary school students. This study included pre-experimental research involving 36 students as research subjects consisting of 18 male students and 18 female students. The research design used was One Group Pretest-Posttest Design involving one group of subjects. This research was carried out through the planning, implementation stage (pre test, treatment and post test), analysis and findings. The research instrument used in this study is a test of students of learning outcomes that describes students' numeracy skills and observation sheets. The results of the research data obtained are then analyzed using technical descriptive statistical analysis and inferential analysis. The data obtained in the form of quantitative data from the results of tests of numeracy skills in topic of the volume of cube and rectangle are then analyzed using descriptive analysis and t-test. From the results of the study obtained the average value of the pre test of 58.61 which is included in the medium category. While the average value of the post test obtained is 80 which is in the high category. Based on the results of the t-test analysis, it is obtained that the $t$ count $=15.39$ and $t$ table $=3.591$, so that it can be written $t$ count $\geq t$ table or $15.39 \geq 3.591$. Thus, it can be concluded that Ho is rejected and $\mathrm{H} 1$ is accepted which illustrates that the use of educational media "Compact Counting" can have an effect in improving students' numeracy skills in volume and cube volume topic.

Keywords: educational media, compact counting, numeracy skill
\end{abstract}




\section{PENDAHULUAN}

Matematika sebagai wahana pendidikan digunakan untuk mencapai satu tujuan, akan tetapi dapat pula untuk membentuk kepribadian murid, serta mengembangkan keterampilan tertentu. Mempelajari matematika merupakan sarana berpikir ilmiah dan berpikir logis serta mempunyai peranan penting dalam upaya peningkatan kualitas sumber daya manusia.

Pembelajaran matematika yang ada di tingkat satuan pendidikan dasar, hingga perguruan tinggi diarahkan mampu mengembangkan kemampuan manusia dalam berpikir secara logis, sistematis, analisis, kritis dan kreatif (Risnawati, 2013). Kemampuan berpikir inilah yang menjadi modal bagi peserta didik dalam bertindak dan mengambil keputusan secara tepat dan cepat sesuai situasi yang ada.Dengan demikian, penguasaan materi matematika menjadi sarana yang penting dalam penguasaan Ilmu Pengetahuan dan Teknologi (IPTEK).

Masalah utama dalam pembelajaran matematika adalah masih rendahnya daya serap peserta didik. Selain itu, banyak siswa tampaknya menjadi tidak tertarik dengan matematika ini dikarenakan belum tepatnya cara penyampaian materi kepada siswa sehingga menyebabkan siswa kesulitan dalam menerima pelajaran.Sebagian besar guru masih mengimplementasikan pembelajaran matematika tradisional yaitu pembelajaran matematika dengan mengandalkan metode tunggal ekspositori dengan siklus; menjelaskan, memberi contoh, mengajukan pertanyaan, dan memberi tugas secara klasikal.

Metode seperti ini mengakibatkan proses pembelajaran berpusat pada guru (student centered) dan proses pembelajaran hanya dikuasai oleh guru. Sehingga minat siswa rendah dalam pembelajaran matematika yang mengakibatkan pemahaman dan penguasaan materi cenderung rendah. Kondisi tersebut akhirnya berdampak pada hasil belajar siswa yang kurang maksimal.
Karim dalam (Puspitasari, 2012: 100) menyatakan bahwa guru matematika sekolah dasar harus memahami materi yang akan diajarkan, memahami dan memanfaatkan dengan baik cara peserta didik belajar matematika, serta memahami dan menerapkan cara memanfaatkan alat bantu belajar mengajar matematika. Oleh karena itu, guru harus berupaya memelihara dan mengembangkan minat atau kesiapan belajar siswanya yaitu dengan menggunakan metode yang tepat dalam melakukan proses pembelajaran dan mengaktifkan siswa agar tetap berminat dan mau memusatkan perhatian pada tugas-tugas matematika.

Semua hal tersebut sangat mendukung keberhasilan siswa dalam pembelajaran matematika. Keberhasilan siswa dalam menyelesaikan soal matematika dapat dilihat dari keterampilan siswa dalam menyelesaikan masalah metematika. Tidak sedikit siswa mengalami kesulitan dalam memecahkan masalah tersebut karena tingkat pemahaman siswa terhadap masalah tersebut masih kurang.

Sebagai upaya meningkatkan kemampuan berhitung siswa masih dibutuhkan suatu metode atau media pembelajaran yang efektif, menarik, dan menyenangkan siswa. Dalam hal ini peneliti menggunakan media edukasi Hitung Kompak dalam pembelajaran matematika materi ajar menghitung volume kubus dan balok, dengan penggunaan media tersebut diharapkan siswa bisa lebih aktif, kreatif, serta dapat menguasai pengetahuan mata pelajaran matematika, serta permasalahan rendahnya kemampuan berhitung siswa dapat diatasi.

Media edukasi "Hitung Kompak" merupakan suatu media yang didesain untuk memecahkan masalah pembelajaran matematika yang terdiri atas, papan alas berbasis permainan ular tangga dan dilengkapi dengan kartu hitung dari kertas berwarna. Penggunaan media edukasi "Hitung Kompak" pada proses pembelajaran matematika merupakan variasi dalam proses pembelajaran Copyright @2019, JRPD, ISSN 2615 - 1723 (Print), ISSN 2615 - 1766 (Online) 
yang dapat menciptakan proses pembelajaran dengan nuansa bermain, sehingga siswa tidak merasa jenuh dan bosan dalam mengikuti pembelajaran matematika di kelas.

\section{METODE}

Penelitian ini merupakanpenelitian praeksperimen dengan rancangan One Group Pretest-Posttest Design. Adapun cara atau teknik dalam pengambilan sampel yang digunakan adalah teknik random sampling atau biasa juga diberi istilah pengambilan sampel secara rambang atau acak.

Adapun sampel penelitian yang dimaksud adalah siswa kelas V.C SD Inpres Maccini kota Makassar yang berjumlah 36 orang, terdiri dari 18 laki-laki dan 18 perempuan. Peneliti mengambil sampel kelas V.C, karena berdasarkan informasi dari pihak sekolah nilai rata-rata hasil belajar di kelas tersebut selalu dibawah standar kriteria ketuntasan minimal (KKM), sehingga perlu diadakan suatu inovasi dalam pembelajaran matematika baik dalam hal metode maupun media pembelajaran yang digunakan.

Adapun instrumen yang digunakan dalam penelitian ini adalah lembar tes hasil belajar kemampuan berhitung dan lembar observasi siswa. Tes kemampuan berhitung ini diberikan sebanyak dua kali kepada subyek penelitian, yaitu sebelum diberikan perlakuan (pre-test) dan setelah diberikan perlakuan (posttest). Untuk menganalisi data yang diperoleh dari hasil penelitian akan digunakan analisis statistik deskriptif dan inferensial.

Analisis statistik deskriptif dimaksudkan untuk menggambarkan hasil belajar matematika siswa kelas V.C SD Inpres Maccini Kota Makassar sebelum (pretest) dan sesudah (posttest) perlakuan berupa penggunaan media edukasi "Hitung Kompak" dengan menggunakan tabel distribusi frekuensi dan persentase dengan rumus persentase, yaitu :

$$
P=\frac{f}{N} x 100 \% \text { (Arikunto, 2006) }
$$

Keterangan:

P : Persentase

f : Frekuensi yang dicari persentase

$\mathrm{N}$ : Jumlah sampel

Guna memperoleh gambaran hasil kemampuan berhitung siswa kelas V.C SD Inpres Maccini Kota Makassar sebelum dan sesudah diberikan penggunaan media edukasi "Hitung Kompak" maka dilakukan perhitungan rata-rata skor peubah dengan rumus:

$$
M e=\frac{\sum X i}{N}
$$

\section{Keterangan:}

Me : Mean (rata-rata)

$\mathrm{Xi} \quad$ : Nilai $\mathrm{X}$ ke i sampai ke $\mathrm{n}$

$\mathrm{N}$ : Jumlahsampel

Setelah rata-rata skor telah diperoleh, maka peneliti mengklasifikasi skor tersebut berdasarkan pengkategorisasian hasil belajar matematika siswa menurut standar kategorisasi yang dilakukan oleh Departemen Pendidikan Nasional (2006) yang dijabarkan sebagai berikut:

Tabel 1 Kategorisasi Standar Hasil Belajar

\begin{tabular}{ccc}
\hline No & Interval & Kategori \\
\hline 1 & $0 \leq \mathrm{x}<55$ & Sangat Rendah \\
2 & $55 \leq \mathrm{x}<70$ & Rendah \\
3 & $70 \leq \mathrm{x}<80$ & Sedang \\
4 & $80 \leq \mathrm{x}<90$ & Tinggi \\
5 & $90 \leq \mathrm{x}<100$ & Sangat Tinggi \\
\hline
\end{tabular}

Sementara analisis statistik inferensial dimaksudkan untuk menguji hipotesis penelitian mengenai ada tidaknya pengaruh penggunaan media edukasi "Hitung Kompak" terhadap kemampuan berhitung siswa kelas V.C SD Inpres Maccini Kota Makassar. Adapun rumus yang digunakan adalah:

$$
t=\frac{M d}{\sqrt{\frac{\sum X^{2} d}{N(N-1)}}} \text { (Arikunto, 2006) }
$$


Keterangan :

$\mathrm{Md}$ : mean dari perbedaan pretest dan posstest

$\mathrm{X} 1$ : hasil belajar sebelum perlakuan (pretest)

$\mathrm{X} 2$ : hasil belajar sesudah perlakuan (posttest)

$\mathrm{d}$ : deviasi masing-masing subjek

$\sum_{\mathrm{x}} 2 \mathrm{~d}$ : jumlah kuadrat deviasi

$\mathrm{N}$ : jumlah sampel

$\mathrm{db}$ : ditentukan dengan $\mathrm{N}-1$

Selanjutnya peneliti menentukan aturan pengambilan atau kriteria yang signifikan dengan kaidah pengujian signifikan terkait hipotesis penelitian yang diajukan dalam penelitian ini adalah sebagai berikut:

1. Jika $\mathrm{t}$ Hitung $>\mathrm{t}$ Tabel maka $\mathrm{H}_{0}$ ditolak dan $\mathrm{H}_{1}$ diterima, hal ini menjelaskan berarti bahwa penggunaan media edukasi "Hitung Kompak" berpengaruh terhadap kemampuan berhitung siswa kelas V.C SD Inpres Maccini Kota Makassar.

2. Jikat $\mathrm{t}$ Hitung $<\mathrm{t}$ Tabel maka $\mathrm{H}_{0}$ diterima, berarti penggunaan media edukasi "Hitung Kompak"tidak berpengaruh terhadap terhadap kemampuan berhitung siswa kelas V.C SD Inpres Maccini Kota Makassar.

3. Mencari $t$ Tabel dengan menggunakan tabel distribusi dengan taraf signifikan $\alpha$ 0,05 dan $\mathrm{db}=\mathrm{N}-1$.

4. Membuat kesimpulan terkait hipotesis penelitian yaitu penggunaan media edukasi "Hitung Kompak"berpengaruh terhadap terhadap kemampuan berhitung siswa kelas V.C SD Inpres Maccini Kota Makassar.

\section{HASIL DAN PEMBAHASAN}

\section{Deskripsi Kemampuan Berhitung Siswa sebelum (pretest) dan setelah (postest) digunakan Media Edukasi Hitung Kompak}

Berdasarkantes hasil belajar keterampilan berhitung siswa sebelum dan setelah diberikan perlakuan yaitu menggunakan Media Edukasi Hitung Kompak pada siswa kelas V.C SD Inpres Maccini, maka diperoleh data-data yang dikumpulkan melalui instrumen tes. Data hasil belajar kelas V.C SD Inpres Maccini dapat diketahui sebagai berikut:

Tabel 2 Hasil Tes Kemampuan Berhitung Siswa

\begin{tabular}{cccccc}
\hline No. Aktivitas & $\begin{array}{c}\text { Skor } \\
\text { rata- } \\
\text { rata }\end{array}$ & Kategori & $\begin{array}{c}\text { Skor } \\
<70\end{array}$ & $\begin{array}{c}\text { Skor } \\
\geq 70\end{array}$ \\
\hline 1 & Pretest & 58.61 & Rendah & 24 & 12 \\
2 & Postest & 81.94 & Tinggi & 3 & 33 \\
\hline
\end{tabular}

Berdasarkan Tabel 2 di atas, dapat dideskripsikan bahwa pada kegiatan prestestdari rentang nilai 10 sampai 100, siswa yang mendapat nilai minimal 70 sebanyak 12 siswa (33.3\%) sedangkan siswa yang mendapat nilai kurang dari 70 sebanyak 24 siswa (66.7\%) dari jumlah sampel. Dengan demikian, dapat dijelaskanbahwa kemampuan berhitung siswa sebelum menggunakan media edukasi "Hitung Kompak" belum tuntas karena jumlah siswa yang memperoleh nilai yang mencapai kriteria ketuntasan minimal (KKM) pada hasil tes kemampuan berhitung siswa yaitu hanya mencapai $33.3 \%$.

Sementara pada kegiatan posttest, siswa yang mendapat nilai $70 \mathrm{ke}$ atas sebanyak 33 siswa (91.67\%) sedangkan siswa yang mendapat nilai 70 ke bawah sebanyak 3 siswa (8.33\%) dari jumlah sampel. Dengan demikian, dapat dikatakan bahwa kemampuan berhitung pada siswa setelah diterapkan penggunaan media edukasi "Hitung Kompak" dalam pembelajaran matematika pada materi volume kubus dan balok sudah tuntas karena skor siswa yang mencapai kriteria ketuntasan minimal mencapai $91.67 \%$.

Jika ditinjau dari rata-rata hasil belajar atau tes kemampuan berhitung siswa, pada aktivitas pretest skor rata-rata yang diperoleh adalah 58.61 dimana skor rata-rata ini termasuk pada kategori rendah. Sementara skor rata-rata yang diperoleh siswa pada aktivitas posttest adalah 81.94 yang berada pada kategori tinggi. Hal ini mengindikasikan bahwa terdapat peningkatan hasil belajar atau kemampuan berhitung siswa setelah Copyright $\odot 2019$, JRPD, ISSN 2615 - 1723 (Print), ISSN 2615 - 1766 (Online) 
Agustan Syamsuddin, Asrul Lukman

diterapkan atau digunakan media edukasi "Hitung Kompak" dalam pembelajaran matematika di kelas VC, SD Inpres Maccini pada materi volume kubus dan balok.

Pengaruh Penggunaan Media Edukasi Hitung Kompak terhadap Kemampuan Berhitung Campuran pada Siswa Kelas V.CSD Inpres Maccini

Sesuai dengan hipotesis penelitian yakni "Terdapat pengaruh penggunaan media edukasi hitung kompak dalam meningkatkan keterampilan berhitung pada mata pelajaran matematika siswa kelas VC SD Inpres Maccini Kota Makassar". Maka teknik yang digunakan untuk menguji hipotesis tersebut adalah teknik statistik inferensial dengan menggunakan uji-t.

Berikut disajikan langkah-langkah untuk melakukan pengujian hipotesis adalah sebagai berikut

1. Mencari nilai "Md" dengan menggunakan rumus:

$$
\begin{aligned}
\mathrm{Md} & =\frac{\sum d}{N} \\
& =\frac{840}{36} \\
& =23.33
\end{aligned}
$$

2. Mencari nilai " $\sum X^{2} d "$ dengan menggunakan rumus :

$$
\begin{aligned}
\sum X^{2} d & =\sum d^{2}-\frac{\left(\sum d\right)^{2}}{N} \\
& =21.800-\frac{\left(840^{2}\right)}{36} \\
& =21.800-\frac{705.600}{36} \\
& =21.800-19.600 \\
& =2.200
\end{aligned}
$$

3. Menentukan nilai $t$ hitung dengan menggunakan rumus :

$$
\mathrm{t} \quad=\frac{M d}{\sqrt{\frac{\sum x^{2} d}{N(N-1)}}}
$$

$$
\begin{array}{ll}
\mathrm{t} & =\frac{23,33}{\sqrt{\frac{2.200}{36(36-1)}}} \\
\mathrm{t} & =\frac{23.33}{\sqrt{\frac{2200}{1.260}}} \\
\mathrm{t} & =\frac{23.33}{\sqrt{1.74603}} \\
\mathrm{t} & =\frac{23,33}{1,32} \\
\mathrm{t} & =17,65
\end{array}
$$

4. Menentukan nilai $t_{\text {tabel }}$

Untuk mencari $t_{\text {Tabel }}$ peneliti menggunakan tabel distribusi $\mathrm{t}$ dengan taraf signifikan $\alpha=0,05$ dan d.b. $=\mathrm{N}-1=36-1=$ 35.

Berdasarkan tabel $\mathrm{t}$, maka diperoleh $\mathrm{t}_{0,05}=3,591$.Setelah diperoleh $\mathrm{t}_{\text {Hitung }}=17,65$ dan $\mathrm{t}_{\text {Tabel }}=3,591$ maka dapat dijelaskan bahwa $\mathrm{t}$ Hitung $\geq \mathrm{t}_{\text {Tabel }}$ atau $17,65 \geq 3,591$. Sehingga dapat disimpulkan bahwa $\mathrm{H}_{0}$ ditolak dan $\mathrm{H}_{1}$ diterima. Ini berarti bahwa penggunaan media edukasi "Hitung Kompak" memiliki pengaruh terhadap kemampuan berhitung pada siswa kelas VCSD Inpres Maccini, Makassar.

Berdasarkan hasil analisis statistik deskriptif dan statistik inferensial yang diperoleh serta hasil observasi yang dilakukan, dapat disimpulkan bahwa terdapat pengaruh penggunaan Media Edukasi Hitung Kompak terhadap kemampuan berhitung pada siswa kelas V.C SD Inpres Maccini Kota Makassar pada materi volume kubus dan balok.

Dengan demikian dapat dijelaskan bahwa pemanfaatan media pembelajaran memberi dampak yang baik terhadap kemampuan siswa dalam pembelajaran. Hal ini sejalan dengan hasil penelitian DePorter dalam (Marisa, 2011: 1.7) bahwa berbagai pemanfaatan media dalam pembelajaran menunjukkan jika media tersebut berdampak positif dalam pembelajaran. Sebuah gambar lebih berarti dari seribu kata yang berarti bahwa penggunaan alat peraga dalam mengawali proses belajar akan merangsang modalitas visual dan menyalakan jalur syaraf sehingga memunculkan beribu-ribu asosiasi dalam kesadaran siswa. Rangsangan visual 
dan asosiasi ini akan memberikan suasana yang sangat kaya untuk pembelajaran.

Selanjutnya secara lebih mendalam, Marisa (2011: 1.7-1.10) membahas beberapa alasan mengenai media pembelajaran perlu digunakan dalam proses pembelajaran yaitu; (1) pembelajaran menjadi lebih menarik dan interaktif; (2) pembelajaran menjadi lebih konkret dan nyata; (3) mempersingkat proses penjelasan materi pembelajaran; mendorong siswa belajar secara lebih mandiri; (5) materi pembelajaran menjadi lebih terstandarisasi. Bila guru menyampaikan materi pembelajaran menggunakan media tertentu, maka setiap siswa akan mendapatkan materi pembelajaran yang sama.

Begitu juga dengan pembelajaran matematika yang sangat membutuhkan media dalam hal ini media edukasi "Hitung Kompak" untuk mempermudah guru dalam menyampaikan materi. Apalagi ketika siswa menghadapi hal yang barudalam rangka menyampaikan pembelajaran yang dapat mengembangkan kompetensi dasar berhitung siswa. Dimana kemampuan berhitung ini merupakan hal yang esensi yang harus dikuasai oleh siswa dalam pembelajaran matematika (Nur, 2013). Berkaitan dengan berhitung, Abdurrahman (2003: 51) menyatakan bahwa berhitung merupakan cabang matematika yang berkenaan dengan sifat dan hubungan bilangan-bilangan nyata dengan perhitungan terutama menyangkut penjumlahan, pengurangan, perkalian, dan pembagian.

Selanjutnya, Susilo dalam Marlina dan Purwadi (2015) menjelaskan mengenai keterampilanmenghitung berkaitan dengan perkembangan berpikir anak, anak sedang berada pada tahap berpikir kongkret saja. Anak memahami bilangan tiga dari tiga buah jeruk. Keterampilan menghitung juga mencakup koordinasi memegang dan menunjuk benda, menyebut angka, dan mengingat urutannya. Ini memang cukup sulit bagi anak sehingga membutuhkan waktu lama baginya untuk secara sungguh-sungguh mengenal bilangan yang mewakili sejumlah benda.

Berdasarkan paparan sebelumnya, hal ini juga terjadi di lapangan ketika peneliti mengambil data penelitian di sekolah. Sebagai contoh, ketika peneliti memberikan masalah baru terkait materi volume dan panjang sisi suatu bangun datar, siswa mengalami kendala dalam memahami konsep berhitung terutama dalam mencari salah satu panjang sisi jika diketahui volume kubus atau balok. Tampak sebagian siswa mengalami kebingungan, hanya tinggal diam, dan kurang bersemangat. Menurutnya, sulit mencari salah satu panjang sisi kubus atau balok, jika volumenya diketahui, sehingga segala yang diharapkan dari guru sulit ditemukan. Dalam hal ini, siswa mengalami kesulitan mengenai menghitung panjang sisi kubus atau balok apabila volumenya diketahui yang membuat siswa jenuh, malas, dan kurang bergairah untuk mengerjakan soal tersebut.

Fenomena lain yang tampak, yaitu ketika siswa menjawab pertanyaan berdasarkan indikator pencapaian hasil belajar memahami volume kubus dan balok, waktu yang digunakan rata-rata lama dan melewati batas waktu 3 x 35 menit. Hal ini disebabkan oleh kurangnya semangat siswa dan sulitnya siswa memahami konsep menghitung volume kubus dan balok.

Setelah menggunakan media edukasi "Hitung Kompak", siswa lebih mudah menyelesaikan/menghitung volume kubus dan balok, karena siswa mengerjakan soal secara berkelompok sehingga mereka dapat saling bertukar pikiran dalam menyelesaikan soal menghitung volume kubus dan balok, dan siswa yang sudah memahami cara menghitung volume kubus dan balok dapat membimbing teman kelompoknya yang belum paham. Selain itu, setiap kelompok bersemangat dalam mengerjakan soal, karena pemberian soal disajikan dalam bentuk permainan dengan menggunakan media edukasi "Hitung Kompak". 
Fenomena menunjukkan bahwa siswa kurang mengalami kendala dalam menyelesaikan soal menghitung volume kubus dan balok, tampak semua siswa bersemangat dalam belajar. Menurutnya, mudah memahami konsep dan menyelesaikan soal menghitung volume kubus dan balok, sehingga segala yang diharapkan dari guru mudah dipahami. Dalam hal ini, siswa mampu memahami cara menghitung volume kubus dan balok.

Fenomena lain yang tampak yaitu ketika siswa menjawab pertanyaan berdasarkan indikator pencapaian hasil belajar kemampuan menghitung volume kubus dan balok. Waktu yang digunakan sesuai dengan target waktu 2 × 35 menit. Bahkan, ada siswa yang mampu menyelesaikan soal selama kurang dari 60 menit. Hal ini mengindikasikan bahwa media edukasi "Hitung Kompak" cocok digunakan dalam pembelajaran matematika tingkat sekolah dasar. Selain itu, dengan menggunakan media edukasi "Hitung Kompak" tentunya berdampak positif terhadap nilai akhir kemampuan berhitung yang diperoleh siswa.

\section{SIMPULAN}

Berdasarkan hasil penelitian, dapat dideskripsikan bahw nilai yang diperoleh siswa sebelum menggunakan media edukasi "Hitung Kompak" yang mencapai standar minimal ketuntasan atau keberhasilan belajar siswa hanya mencapai 33,4\% atau sebanyak 12 siswa yang mendapat nilai 70 ke atas. Setelah menggunakan media edukasi "Hitung Kompak", kemampuan menghitung volume kubus dan balok siswa dikategorikan tuntas dengan siswa yang mendapat nilai di atas 70 sebanyak 33 orang $(91,67 \%)$ dari jumlah sampel dan siswa yang mendapat nilai di bawah 70 sebanyak 3 orang $(8,33 \%)$ dari jumlah sampel. Pengaruh penggunaan media edukasi "Hitung Kompak" diketahui pula berdasarkan perhitungan uji $t$. Perbandingan hasil kemampuan berhitung siswa pada kegiatan pretest dan posttest menunjukkan bahwa nilai $t_{\text {hitung }}$ sebanyak $17.65>\mathrm{t}_{\text {Tabel }}=3.591$. Hal ini menunjukkan bahwa hipotesis penelitian yang diajukan diterima yaitu penggunaan media edukasi "Hitung Kompak" berpengaruh terhadap kemampuan atau keterampilan berhitung siswa pada materivolume kubus dan balok pada siswa kelas VC SD Inpres Maccini, Makassar.

Berdasarkan temuan tersebut, maka dikemukakan beberapa saran sebagai berikut: (1) pada setiap pembelajaran matematika di kelas, sebaiknya siswa diberi atau dilatihkan masalah baru yang berbeda dengan masalahmasalah rutin yang biasa dihadapi oleh siswa sehingga bisa meningktakan keterampilan berhitung siswa; (2) Guru sebaiknya menggunakan media edukasi "Hitung Kompak"sebagai alternatif pemilihan media pembelajaran matematika pada materi menghitung volume kubus dan balok untuk memudahkan guru menyampaikan materi yang diajarkan di kelas sehingga siswa dapat memahami dengan mudah materi yang sedang dipelajarinya; (3) penelitian ini hanya fokus pada materi volume kubus dan balok, dengan demikian untuk pengembangan penelitian ini direkomendasikan kepada peneliti lain untuk meneliti dengan materi yang berbeda dan subyek penelitian yang berbeda pula.

\section{DAFTAR PUSTAKA}

Abdurrahman. (2003). Pendidikan bagi anak berkesulitan belajar. Jakarta: PT Rineka Cipta.

Arikunto, S. (2006). Prosedur penelitian suatu pendekatan praktek. Jakarta: Rineka Cipta.

Departemen Pendidikan Nasional. (2006). Peraturan menteri pendidikan nasional nomor 22 tahun 2006, tentang sistem pendidikan nasional. Jakarta:

Departemen Pendidikan Nasional.

Diah P., Maria Fransiska, dkk. (2013). Studi deskriptif tentang media permainan ular tangga untuk meningkatkan prestasi 
berhitung kelas ii. Prediksi Kajian Ilmiah Psikologi, 2 (1): 39-44.

Endah, M. (2012). Mengajarkan matematika dengan fun. Yogyakarta: MentariPustaka.

Marisa. (2011). Komputer dan media pembelajaran. Jakarta: Universitas Terbuka.

Marlina, Ririn dan Purwadi. (2015). Upaya meningkatkan kemampuan berhitung melalui model pembelajaran kooperatif struktural permainan ulartanggatk marta'ush shibyan singocandi kudus. Jurnal Penelitian PAUDIA. 1 (1): 63-83.

Montolalu. (2005). Bermain dan permainan anak. Jakarta:Universitas Terbuka.

Nur, S. (2013). Meningkatkan Kemampuan Berhitung Awal melalui Permainan Kubus Bergambar pada Anak Kelompok B3 di TK Plus Tunas Bangsa Sooko Mojokerto. PAUD Teratai. 2 (1): 1-14.

Puspitasari, E. (2012). Peningkatan hasil belajar matematika pada materi operasi hitung campuran dengan media kartu hitung kelas V MI miftahul Huda Perak Jombang. PGMI Madrasatuna. 04 (01): 98-125.

Sadiman \& Arief S. (2005). Media pendidikan. Jakarta: PT Raja Grafindo Persada.

Sugiono. (2016). Metode penelitian pendidikan pendekatan kuantitatif, kualitatif dan $R \& D$. Bandung: Alfabeta.

Ulfah, A. (2010). Upaya Meningkatkan Kemampuan Berhitung Siswa Kelas II SD melalui Media Permainan Utang (Ular Tangga). Didaktika, 4 (1): 402-434. 